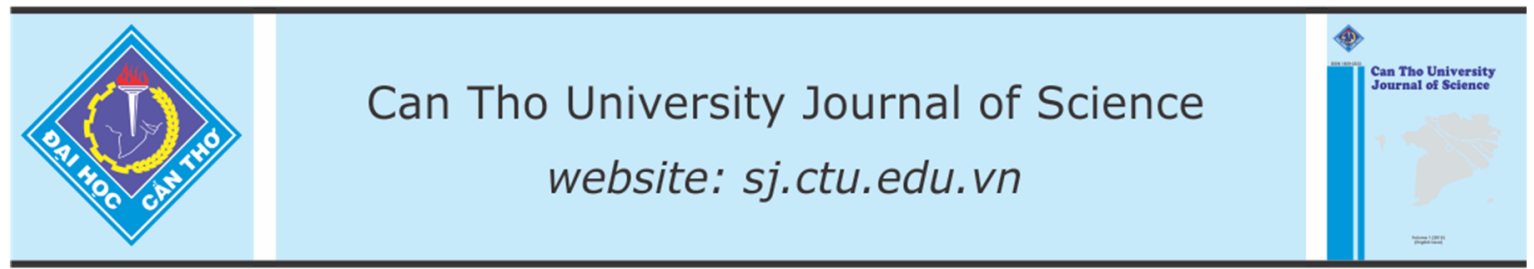

DOI: $10.22144 /$ ctu.jen.2016.046

\title{
PHYSICO-CHEMICAL PROPERTIES OF FOURTEEN POPULAR COCOA BEAN VARIETIES IN DONGNAI - HIGHLAND VIETNAM
}

Lam Thi Viet Ha ${ }^{1,3}$, Bangun Nusantoro ${ }^{3}$, Roger Aidoo Phillip ${ }^{3}$, Phan Huynh Anh ${ }^{1}$, Ha Thanh Toan ${ }^{2}$, Kathy Messens ${ }^{3}$ and Koen Dewettinck ${ }^{3}$

${ }^{1}$ College of Agriculture and Applied Biology, Can Tho University, Vietnam

${ }^{2}$ Biotechnology Research and Development Institute, Can Tho University, Vietnam

${ }^{3}$ Ghent University, Belgium

Article info.

Received date: $26 / 01 / 2016$

Accepted date: $30 / 11 / 2016$

Keywords

Bean dimension, bean mass, cocoa, chemical property

\begin{abstract}
Cocoa (Theobroma cacao L.) is a major, crucial economic, global crop and has been maintained several nutritional benefits. The exporting volume of Vietnamese cocoa bean is increasing in the world cocoa trade. The beans of fourteen popular cocoa varieties that are commonly cultivated in Trang Bom (Dong Nai, Vietnam) were characterized for their physico-chemical qualifications on the background of post-fermented cocoa beans and dehydration in the region of Trang Bom-Dong Nai. The physical properties were determined based on mass ratio and bean's dimension (lengh, width and thickness) as well as chemical (proximate) composition (total crude protein, ash, moisture, and lipid). These values were analysed using AOAC methods. The largest-size beans were found for the TD8 variety (1.5 g of mass, $25.02 \mathrm{~mm}$ of length, $14.28 \mathrm{~mm}$ of width and $7.96 \mathrm{~mm}$ of thickness). The moisture content of the cocoa beans was in the range between 5.64 and $6.99(\% \mathrm{wb})$ and the ash content in the range between $3.67 \%$ and $2.47 \%(w b)$. Noticeably, the fat content ratio (the most important value of cocoa bean) found in 8 varieties (TD1, TD2, TD5, TD9, TD11, TD12, TD13, TD14) was over 50\%, thus these varieties are worthy chemical component especially for exported cocoa bean and industrized cultivation (extending the cultivation producing area).
\end{abstract}

Cited as: Ha, L.T.V, Nusantoro, B., Phillip, R.A., Anh, P.H., Toan, H.T., Messens, K. and Dewettinck, K., 2016. Physico-chemical properties of fourteen popular cocoa bean varieties in Dongnai highland Vietnam. Can Tho University Journal of Science. Vol 4: 81-86.

\section{INTRODUCTION}

Cocoa beans are harvested from cocoa trees (Theobroma cacao L.) (Lecumberri et al., 2007) and provide enormous benefits to producing countries by boosting their economies as well as providing good nutrition to consumers (Aremu et al., 1995; Wood and Lass, 2008; Efombagn et al., 2009; Ha et al., 2015a). Cocoa-originated food has long been consumed as far back as the eighteenth century (Lecumberri et al., 2007).
Currently, Vietnam focuses mainly on investment of producing cocoa beans for exportation since cocoa beans of Vietnamese origin are now of good quality and as such able to compete with cocoa beans from other top-exporting countries (Ha et al., 2015b). Cocoa trees are well adapted to the climate and soil of southern Vietnam (Phuoc, 2009; Hau, 2011). The highest bean yield has since been reported from Mekong Delta and Central Highlands of Vietnam. Most of the recent studies have focused on the breeding and selection of high-yield cocoa varieties in Ben Tre and Can Tho (Hau et al., 
2010; Hau and Ngan, 2011). Other studies that are conducted on quality of cocoa beans of central highlands have not been published yet, nevertheless this region has been reported to produce very high yield of cocoa beans.

The physical properties of beans (size and mass) are factors that influence the quality of beans during the time of transportation and preservation (Bart-Plange and Baryeh, 2003). These factors have been investigated on soya beans (Deshpande et al., 1993), cumin beans (Singh and Goswani, 1996), bambara seeds (Baryeh, 2001) and several other seeds.

This work compared fourteen dried fermented cocoa beans (TD1, TD2, TD3, TD5, TD6, TD7, TD8, TD9, TD10, TD11, TD12, TD13, TD14, and TD15) of Trinitario hybrids (Phuoc, 2009; Ve et al., 2011; Ha et al., 2015b). Ten out of the fourteen varieties were certified by Ministry of Agriculture and Rural Development. Trinitario hybrids are a cross between Criollo and Forastero groups. The Criollo groups are attributed with palatable flavor but are vulnerable to pathologies while Forastero groups have high-yield traits but mediocre flavor (Lachenaud et al., 2007; Wood and Lass, 2008; Ha et al., 2015a). All analyses were done using AOAC methods (AOAC Official Methods of Analysis, 1998). The data obtained in this work provide the basis for further breeding programmes of cocoa beans from southern Vietnam.

\section{MATERIALS AND METHODS}

\subsection{Cocoa bean preparation}

Fourteen cocoa varieties were individually collected at cocoa farm in the region of Trang Bom-Dong Nai in two cocoa reasons (May-July) and (OctoberDecember) in 2015. The origin of 14 varieties is from Malaysia and they were imported and planted in Vietnam from $90^{\text {th }}$ (Phuoc, 2009). In addition, this research was conducted in order to investigate the correlation between the DNA relationship and the bean quality of 14 Vietnamese cocoa bean varieties. Therefore, the individual separation of each cocoa bean variety is a crucial work during harvest, fermentation and drying processing.

\subsection{Processing of drying cocoa beans}

Cocoa pulp was removed and fermented from harvested cocoa pods. Raw seeds of fourteen varieties were individually fermented in wooden barrels (6-7 days duration). After fermentation, cocoa seeds were naturally dried under the sun light, varying greatly according to seasons of the year (approximately $30^{\circ} \mathrm{C}$ in the summer) for 7-8 days (Kyi et al., 2005; Phuoc, 2009).

\subsection{Size of bean}

The length, width and thickness of cocoa beans were measured according to Murray method (Leishman and Murray, 2001). Shape and diameter of cocoa bean were measured by Micrometer screw gauge with $0.01 \mathrm{~mm}$ accuracy (Stainless Steel Electronic LCD Digital Vernier Caliper Gauge Micrometer 0-6" Range) (Bart-Plange and Baryeh, 2003) (Fig.1). Ten seeds randomly selected from 10 subsamples consisting of 100 seeds were measured and the mean values were analysed (Singh and Goswani, 1996; Aviara et al., 1999).

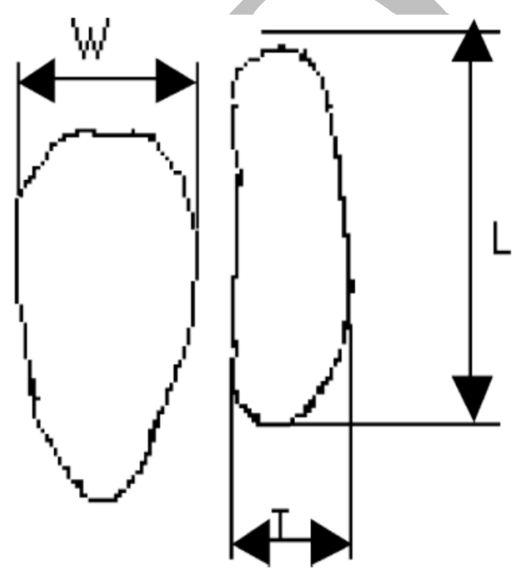

Fig. 1: Cocoa bean's size and measurements (length, width and thickness)

\subsection{Bean mass}

The dehyrated cocoa beans were randomly selected and weighed on an electronic balance with $0.01 \mathrm{~g}$ accuracy. The experiments were randomly repeated (5 x 100 random seeds) and mean values were calculated (Deshpande et al., 1993; Srinath et al., 1996, Aviara et al., 1999). The final values were divided by 100 to acquire the bean mass.

\subsection{Sampling preparation}

Cocoa beans were processed followed by AOAC 935.52. (AOAC Internation 1998. AOAC official method 935.52. Nuts and Nut products. Preparation of sample. Crude cocoa bean collected at the cocoa centres and farms were analysed at FTE lab (Ghent University, Belgium). Cocoa beans were dehusked, grinded and refined (Hamilton Beach 80365 Custom Grind Hands-Free Coffee Grinder, Platinum). The refined cocoa particles were analysed for required characteristics.

\subsection{Chemical analyzing methods (moisture, ash, lipid, and crude protein content)}

Moisture content was examined by AOAC 925.40 (AOAC International 1998. AOAC official method 925.40. Moisture in Nuts and Nut products). 
Ash content was examined by AOAC 972.15 (AOAC International 1998. AOAC official method 972.15). Ash of Cacao products.

Crude protein content was measured by AOAC 950.48 (AOAC International 1998. AOAC official method 950.48). Protein (crude) in Nuts and Nut products.

Crude fat content was measured by AOAC 948.22 (AOAC International 1998. AOAC official method 948.22). Fat (crude) in Nuts and Nut products.

\subsection{Statistical Analyses}

All the data were analysed using Statgraphics Sta

Table 1: Cocoa bean dimension and mass tistical version 20.0 for ANOVA and Duncan's multiple range test. Least significant difference (LSD) was used to separate and compare the means and significance was accepted at $1 \%$ level $(\mathrm{P} \leq 0.01 \%)$. All treatments were designated in $\mathrm{du}-$ plicate and mean values reported.

\section{RESULTS AND DISCUSSION}

\subsection{Physical properties of cocoa bean (dimension and mass)}

The cocoa bean dimension and mass data are showed in Table 1.

\begin{tabular}{|c|c|c|c|c|}
\hline Cocoa varieties & Mass (g) & Length (mm) & Width (mm) & Thickness (mm) \\
\hline TD1 & $0.95 \mathrm{fg}$ & $19.78 \mathrm{gh}$ & $12.68 \mathrm{def}$ & $7.42 \mathrm{abc}$ \\
\hline TD2 & $1.00 \mathrm{ef}$ & $18.73 \mathrm{i}$ & $11.03 \mathrm{~g}$ & $7.85 \mathrm{a}$ \\
\hline TD3 & $1.13 \mathrm{c}$ & $21.02 \mathrm{f}$ & de & 7.54ab \\
\hline TD5 & $1.05 \mathrm{de}$ & $20.13 \mathrm{gh}$ & $12.48 \mathrm{ef}$ & $6.77 \mathrm{~cd}$ \\
\hline TD6 & $0.98 \mathrm{efg}$ & $21.98 \mathrm{e}$ & $12.90 \mathrm{cde}$ & 7.1bcd \\
\hline TD7 & $1.27 \mathrm{~b}$ & $25.30 \mathrm{a}$ & 13.13bcde & 7.47ab \\
\hline TD8 & $1.50 \mathrm{a}$ & $25.02 \mathrm{ab}$ & $14.28 \mathrm{a}$ & $7.96 \mathrm{a}$ \\
\hline TD9 & $1.33 \mathrm{~b}$ & $25.05 \mathrm{a}$ & $13.53 \mathrm{abcd}$ & $7.11 \mathrm{bcd}$ \\
\hline TD10 & $1.14 \mathrm{c}$ & $24.19 b c$ & $13.83 \mathrm{abc}$ & 7.60ab \\
\hline TD11 & $1.13 \mathrm{~cd}$ & $24.05 c$ & $13.88 \mathrm{ab}$ & $6.76 \mathrm{~d}$ \\
\hline TD12 & $0.96 f g$ & $20.31 \mathrm{fg}$ & $13.12 \mathrm{bcde}$ & 7.44ab \\
\hline TD13 & $1.16 \mathrm{c}$ & $25.76 \mathrm{a}$ & $12.99 \mathrm{bcde}$ & $8.00 \mathrm{a}$ \\
\hline TD14 & $0.92 \mathrm{~g}$ & 19.41hi & $11.80 \mathrm{fg}$ & $7.18 \mathrm{bcd}$ \\
\hline TD15 & $0.97 \mathrm{efg}$ & $23.01 \mathrm{~d}$ & $13.04 \mathrm{bcde}$ & 7.69ab \\
\hline
\end{tabular}

** $P \leq 0.01$ : significant at $1 \%$. The values in each column followed by different normal characters are significantly different (Duncan test, $P<0.05$ )

Data acquired from Duncan test (Table 1) indicates that cocoa bean variety TD8 had the heaviest and largest seed (1.5 g of mass, $25.02 \mathrm{~mm}$ of length, $14.28 \mathrm{~mm}$ of width and $7.96 \mathrm{~mm}$ of thickness). In constrast, cocoa variety TD14 recorded the least values for all measured parameters $(0.92 \mathrm{~g}$ of mass, $19.41 \mathrm{~mm}$ of length, $11.80 \mathrm{~mm}$ of width and 7.18 $\mathrm{mm}$ of thickness). These two varieties should therefore be taken into account by cocoa breeders when looking for cocoa varieties with good yield for large-scale cocoa cultivation. Compared to Ghanaina cocoa beans, TD8 has better bean quality for international exports since Ghanaian cocoa beans only weighs $1.31 \mathrm{~g}$ with other physical quality measurement values being smaller than those of TD8 (Bart-Plange and Baryeh, 2003).

For broader view of cocoa bean size, Hau and Ngan (2011) reported one cocoa variety cultivated in Can Tho (Mekong Delta region) with similarly high values (19-25 $\mathrm{mm}$ of length, $12-13 \mathrm{~mm}$ of width, 7.2-9.9 mm of thickness) compared to Ghanaian cocoa bean size. This shows that some cocoa varieties cultivated in the southern of Vietnam adapt well to soil and climate and obtain better bean quality.

\subsection{Chemical composition analysis}

\subsubsection{Moisture and ash content}

The data are presented in table 2 .

Table 2 shows the moisture content of 14 varieties ranged from 5.64 to $6.99 \%(\mathrm{wb})$ at $0.01 \%$ (LSD) as opposed to that of Ghanaian cocoa beans which is in higher range $5 \%$ to $24 \%$ (wb) (Bart-Plange and Baryeh, 2003). The difference of moisture content between Vietnamese and Ghanaian beans demonstrates that Vietnamese beans contained lower moisture than Ghanaian beans. The lower moisture cocoa beans can be stored more appropriately due to the fact that microbiological and enzymatic reactions are inhibited at low level of moisture. Indeed, the highest value of moisture content found in Vietnamese cocoa bean is only $6.99 \%$ (TD6), while that value of Ghanaian cocoa bean quadruple. 
Table 2: The moisture and ash content of 14 examined cocoa varieties

\begin{tabular}{lrr}
\hline Cocoa Varieties & Moisture (\%) & Ash $\mathbf{~} \%$ \\
\hline TD1 & $5.79 \mathrm{ef}$ & $2.56 \mathrm{de}$ \\
TD2 & $6.09 \mathrm{cdef}$ & $2.61 \mathrm{de}$ \\
TD3 & $6.90 \mathrm{ab}$ & $3.05 \mathrm{bc}$ \\
TD5 & $6.41 \mathrm{bcd}$ & $3.05 \mathrm{bc}$ \\
TD6 & $6.99 \mathrm{a}$ & $2.85 \mathrm{bcd}$ \\
TD7 & $6.23 \mathrm{cde}$ & $2.98 \mathrm{bc}$ \\
TD8 & $5.85 \mathrm{ef}$ & $2.47 \mathrm{e}$ \\
TD9 & $6.47 \mathrm{bc}$ & $2.95 \mathrm{bc}$ \\
TD10 & $5.91 \mathrm{def}$ & $3.03 \mathrm{bc}$ \\
TD11 & $6.00 \mathrm{cdef}$ & $2.95 \mathrm{bc}$ \\
TD12 & $5.64 \mathrm{f}$ & $2.57 \mathrm{de}$ \\
TD13 & $6.11 \mathrm{cdef}$ & $3.14 \mathrm{~b}$ \\
TD14 & $6.20 \mathrm{cde}$ & $2.84 \mathrm{~cd}$ \\
TD15 & $5.99 \mathrm{cdef}$ & $3.67 \mathrm{a}$ \\
\hline
\end{tabular}

** $P \leq 0.01$ : significant at $1 \%$. The values in each column followed by different normal characters are significantly different (Duncan test, $P<0.05$ )
Noticeably, the ash content of Vietnamese cocoa beans $(2.5-3.7 \%)$ is considerably high compared to Ghanaian cocoa beans ash content (2.3-3.5\%) (Afoakwa et al., 2013). This proves that Vietnamese cocoa is rich in minerals since the ash property indicates minerals content. Further expermiments will need to be conducted to further elaborate this.

\subsubsection{Crude protein content}

The crude protein content is illustrated in Figure 2.

The total protein content of the fourteen examined cocoa varieties ranged from 12.82 to $13.94 \%$ (WB) (Fig. 2), this shows that these values are not significantly different. At this point, the protein level of Vietnamese cocoa beans is slightly lower compared to Nigerian and Ghanaian cocoa bean protein level (Nigerian cocoan beans $17.5 \%$ (Aremu et al., 1995), Ghanaian cocoan beans $18.8 \%$ (Afoakwa et al., 2013).

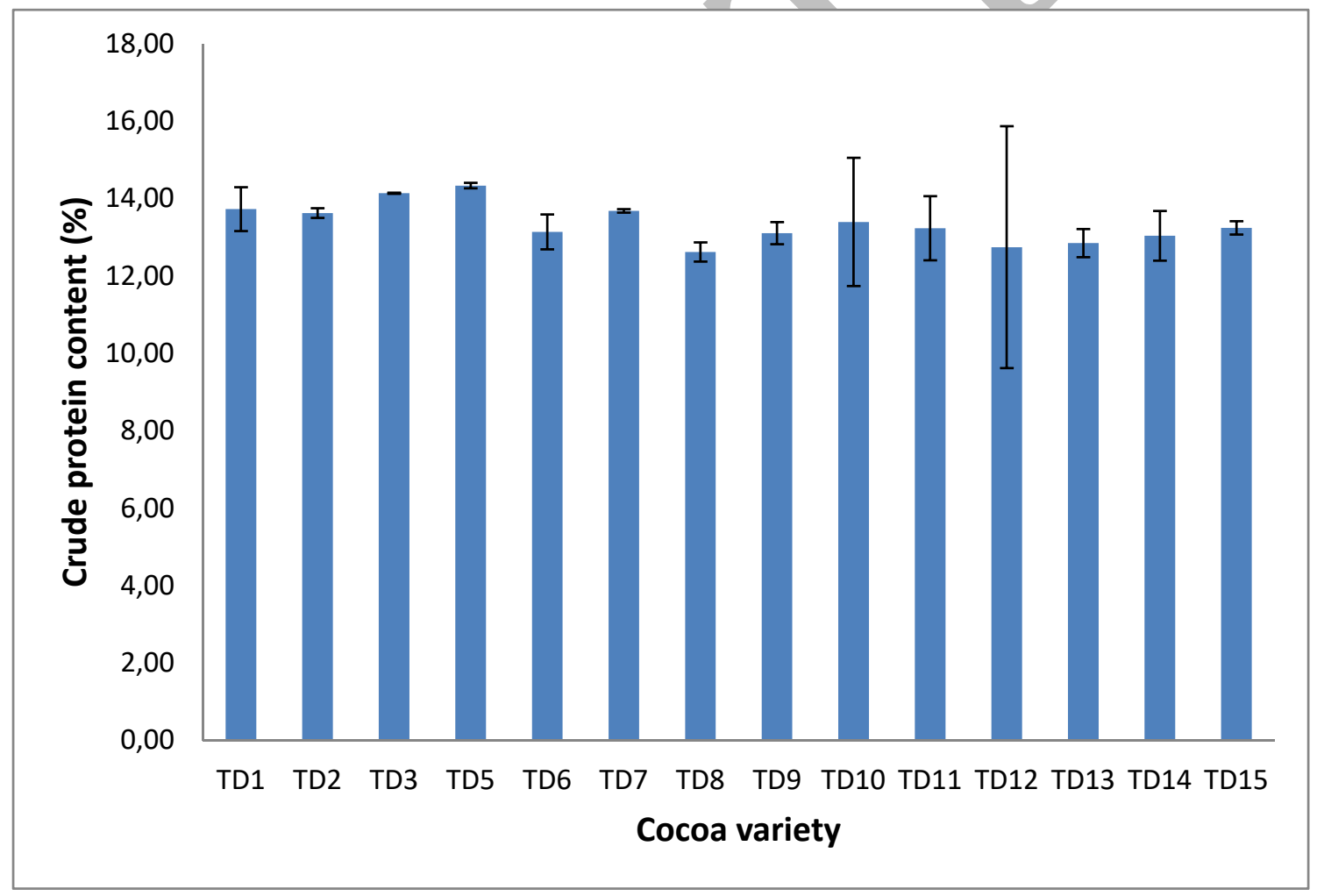

Fig. 2: Total crude protein content of 14 examined cocoa varieties

\subsubsection{Fat content}

The fat content is given in Figure 3. 


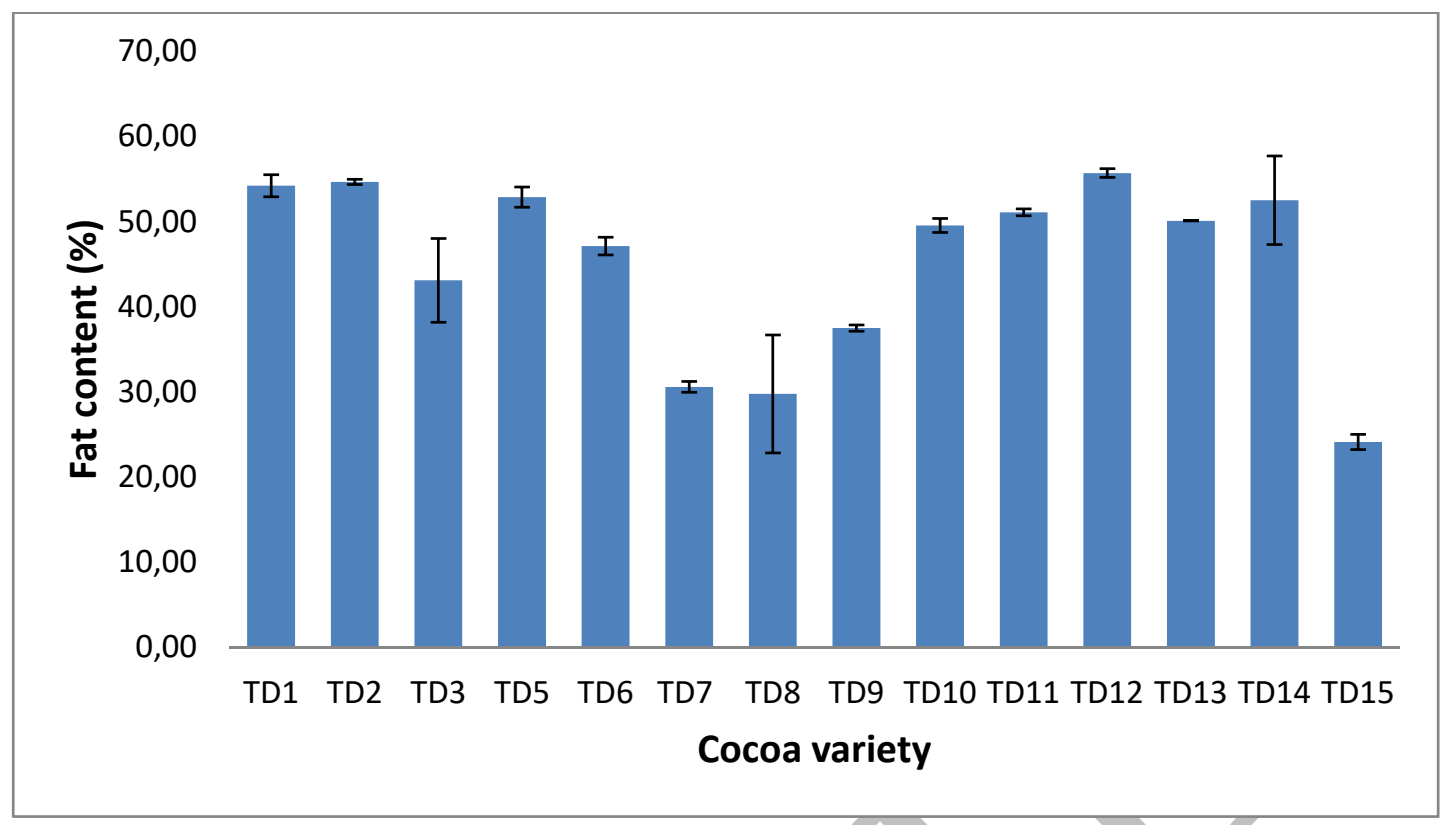

Fig. 3: The fat content of 14 examined cocoa varieties

Based on the fat content values (Fig. 3), the 14 cocoa varieties can be grouped into 3 major groups: group 1 has fat content under $30 \%$, group 2 has fat content between $30 \%$ and $50 \%$ and the last one, group 3 has fat content above 50\%. Namely, group 1 consists of 2 varieties (TD8, TD15) and the lowest value of fat content of this group accounted for $24.12 \%$ (TD15); group 2 has 4 varieties (TD3, TD6, TD7, TD10); group 3 includes 8 varieties (TD1, TD2, TD5, TD9, TD11, TD12, TD13, TD14) and the greatest value of fat content of this group accounted for $55.69 \%$ (TD12). The Vietnamese cocoa fat index is relatively comparable to Ghanaian cocoa fat quality which is approximately 50.40 - 55.21\% (Afoakwa et al., 2013). Due to the fact that yield of cocoa bean is considered to be a pivotal index of the cocoa purchase industry, thus these varieties of group 3 are potentially competitive on international cocoa trade market.

TD1 of group 3 has been cultivated in some provinces of the southern of Vietnam and yielded high fat content according to reports of Hau et al., (2010) and Hau and Tran (2011). Fat content (56\%) was reported for TD1 beans grown in Can Tho and Ben Tre (Mekong Delta region). Based on this fact, it might be concluded that the southern area of Vietnam indeed is well-suited for cocoa tree industrial cultivation and TD1 should primarily be noticed for selecting and breeding projects. The fat index in this research also reveals a paradoxical correlation that the largest size bean TD8 (group 1) resulted in greatly lower fat content, while the smallest size bean TD14 (group 3) attained a higher amount of fat $(>50 \%)$. In contrast, Wood and Lass (2008) and Dand (1997) revealed that lower fat content was found in smaller bean size. This featuring trait should also be marked for cocoa cultivars.

\section{CONCLUSIONS}

Fourteen cocoa varieties from Trang Bom (Dong Nai, Vietnam) were investigated. Bean characteristics such as bean dimension, bean mass and chemical compositions (Protein, Ash, Fat, and Moisture content) were determined. Overall, TD8 bean variety performed best in terms of size and weight (1.5 $\mathrm{g}$ of mass, $25.02 \mathrm{~mm}$ of length, and $7.96 \mathrm{~mm}$ of thickness). The bean size of TD8 was thus comparable to Ghana's cocoa bean. The moisture content of all 14 varieties ranged between $5.64-6.99 \%$ (wb) which was significantly lower than moisture content of cocoa beans from Ghana $(5-24 \% \mathrm{wb})$. All 14 cocoa varieties however recorded similar ash content as Ghanaian cocoa beans. Eight out of the 14 cocoa varieties, namely, TD2, TD5, TD9, TD11, TD12, TD13, TD14, recorded high fat contents (>50\%) with TD12 containing the highest fat content of $55.69 \%$.

Knowledge about the physico-chemical properties of these cocoa varieties would provide the basis for further breeding programmes of cocoa beans and help improve cocoa production sustainability in southern Vietnam. Further experiments will focus on bean properties such as fiber content, polyphenol substances and antioxidants content and establish correlation between the different factors. 


\section{ACKNOWLEDGEMENT}

We sincerely acknowledge the sponsor of Ministry of Education and Trainning on this project. We also extend the grateful attitude to Mr. Vo Ngoc Nuoi (a famer of Cocoa Plantation in Trang BomDong Nai) who greatly contributed to our research.

\section{REFERENCES}

Afoakwa, E.O., Quao, J., Tacrama, J., Budu, A.S., Saalia, F.K., 2013. Chemical composition and physical quality characteristics of Ghanaian's cocoa bean as affected by pulp pre-conditioning and fermentation. Journal of Food Science and Technology. 50: 1097 1105.

AOAC International. 1998. AOAC official method 948.22. Fat (crude) in Nuts and Nut products.

AOAC Internation. 1998. AOAC official method 925.40. Moisture in Nuts and Nut products.

AOAC Internation. 1998. AOAC official method 950.48. Protein (crude) in Nuts and Nut products.

AOAC Internation. 1998. AOAC official method 935.52. Nuts and Nut products. Preparation of sample. Procedure.

AOAC Internation. 1998. AOAC official method 972.15. Ash of Cacao products.

Aremu, C.Y., Agiang, M.A., Ayatse, J.O.I., 1995. Nutrient and antinutrient profiles of raw and fermented cocoa beans. Plant foods for human nutrition. 48 : 217-223.

Aviara, N.A., Gwandzang, M.I., Hague, M.A., 1999 Physical properties of guna seeds. Journal of Agricultural Engineering Research. 73: 105-111.

Bart-Plange, A., Baryeh, E.A., 2003. The physical properties of Category B cocoa beans. Journal of Food Engineering. 60: 219-227.

Baryeh, E.A., 2001. Physical properties of bambara groundnuts. Journal of Food Engineering. 47: 321-326.

Deshpande, S.D., Bal, S., Ojha, T.P., 1993. Physical properties of soybean. Journal of Agricultural Engineering Research. 56: 89-98.

Efombagn, M.I.B., Sounigo, O., Nyasse, S., ManzanaresDauleux, M., Eskes, A.B., 2009. Phenotypic variation of ca cao (Theobroma cacao L.) on farms and in the gene bank in Cameroon. Journal of Plant Breeding and Crop Science. 1: 258-264.
Ha, L.T.V., Vanlerberghe, L., Toan, H.T., Dewettinck, K., Messens, K., 2015a. Comparative Evaluation of Six Extraction Methods for DNA Quantification and PCR Detection in Cocoa and Cocoa-Derived Products. Food Biotechnology. 29:1-19.

Ha, L.T.V., Pha, N.T., Lien, N.T., Nam, T.V.B., Toan, H.T., Dewetinck, K., Messens, K., 2015b. Assessment of Genetic Diversity of the Main Fourteen Cocoa varieties in Vietnam Using plant c/d sequences. Cantho University Journal of Science. 39: 1-6.

Hau, T.V., Ngan, H.T., 2011. The first result of prominent cocoa clones selection at Cantho (Theobroma cacao L.). Journal of Agriculture and Rural Development. 1: 120-127.

Hau, T.V, Thuy, L.T.T., Truc, P.T., 2010. Evaluating of agronomy characteristics and total lipid content in a bean of some cocoa cultivars (Theobroma cacao L.) popular grown in Chau Thanh district, Ben Tre province. Cantho University Journal of Science. 15: 178-185.

Lachenaud, P., Paulin, D., Ducamp, M., Thevenin, J.M., 2007. Twenty years of agronomic evaluation of wild cocoa trees (Theobroma cacao L.) from French Guiana. Scientia horticulturae. 113: 313-321.

Lecumberri, E., Mateos, R., Izquierdo-Pulido, M., Rupérez, P., Goya, L., Bravo, L., 2007. Dietary fibre composition, antioxidant capacity and physicochemical properties of a fibre-rich product from cocoa (Theobroma cacao L.). Food Chemistry. 104: 948-954.

Phuoc, P.H.D., 2009. Cocoa cultivated technique in Vietnam. Vietnam Agriculture Publisher, 1-46.

Kyi, T.M., Daud, W.R.W., Mohammad, A.B., Wahid Samsudin, M., Kadhum, A.A.H., Talib, M.Z.M., 2005. The kinetics of polyphenol degradation during the drying of Malaysian cocoa beans. International Journal of Food Science \& Technology. 40: 323-331.

Robin Dand, 1997. The international cocoa trade. John Wiley \& Sons, London, UK.

Singh, K.K., Goswani, T. K., 1996. Physical properties of cumin. seed. Journal of Agricultural Engineering Research. 64: 93-98.

Srinath, M.D., Rajasekaran, P.K., Viswanathan, R., 1996. Introduction to statistical signal processing with applications.

Ve, N.B., Hau, T.V., Phong, L.T., 2011. Industry Tree Cantho University Publisher, 8-9.

Wood, G.A.R., Lass, R.A., 2008. Cocoa. John Wiley \& Sons, London, UK. 